\title{
General Counsel's Office FY 1995 Site Support Program Plan WBS 6.10.5
}

S. R. Moreno

Date Published

September 1994

Prepared for the U.S. Department of Energy

\section{(2)

Hanford Oparations and Engineering Contractor for the 
LEGAL DISCLAIMER

This report was prepared as an account of work sponsored by an agency of the United States Government. Neither the

United States Government nor any agency thereof, nor any of their employees, nor any of their contractors, subcontractors

or their employees, makes any warranty, express or implied,

or assumes any legal liability or responsibility for the

accuracy, completeness, or any third party's use or the results of such use of any information, apparatus, product, or process disclosed, or represents thet its use would not infringe

privately owned rights. Reference herein to any specific commercial product, process, or service by trede name, trademark, manufacturer, or otherwise, does not necessarily constitute or imply its endorsement, recommendation, or favoring by the United States Government or any agency thereof or its contractors or subcontractors. The views and opinions of authors expressed herein do not necessarily state or reflect those of the United States Government or any agency thereof.

This report has been reproduced from the best available copy. Available in paper copy and microfiche.

Available to the U.S. Department of Energy

and its contractors from

Office of Scientific and Technical Information

P.O. Box 62

Oak Ridge, TN 37831

(615) 536-8401

Available to the public from the U.S. Department of Commerce

National Technical Information Service

5285 Port Royal Road

Springfield, VA 22161

(703) $487-4650$

Prnted in the Unrted States of America

DISCLM-1.CHP (1-91) 


\section{DISCLAIMER}

Portions of this document may be illegible in electronic image products. Images are produced from the best available original document. 


\section{RELEASE AUTHORIZATION}

Document Number: WHC-SP-1141

Document Title: General Counsel's FY 1995 Site Support Program Plan

Release Date: $\quad 9 / 29 / 94$

* * * * * * * * * * * *

This document was reviewed following the procedures described in WHC-CM-3-4 and is:

APPROVED FOR PUBLIC RELEASE

***************

WHC Information Release Administration Specialist:

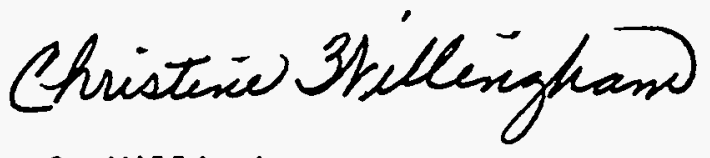

C. Willingham

$\frac{9 / 29 / 94}{\text { (Date) }}$ 
FY 1995

SITE SUPPORT PROGRAM PLAN

GENERAL COUNSEL'S OFFICE

WHC-SP-1141

WBS 6.10 .5

\section{TABLE OF CONTENTS}

APPROVAL SHEET

1.A Vision/Mission

1.B.1 Internal Assessment Summary

1.B.2 External Assessment Summary

1.C Goals and Objectives

1.D Strategies

1.E Assumptions

1.F Issues and Constraints

1.G Performance Measures

2.A.1 Work Breakdown Structure and Responsibility Assignment Matrix

2.A.2 Description of Activities

2.C.1 Cost Baseline by Program Element

2.C.2 Cost Basis

2.C.3 FTE Forecasts

Dictionary 


\section{FY 1995}

\section{Site Support Program Plan Approval Sheet}

\section{GENERAL COUNSEL'S OFFICE}

\section{WHC-SP-1141}

\section{WBS 6.10 .5}

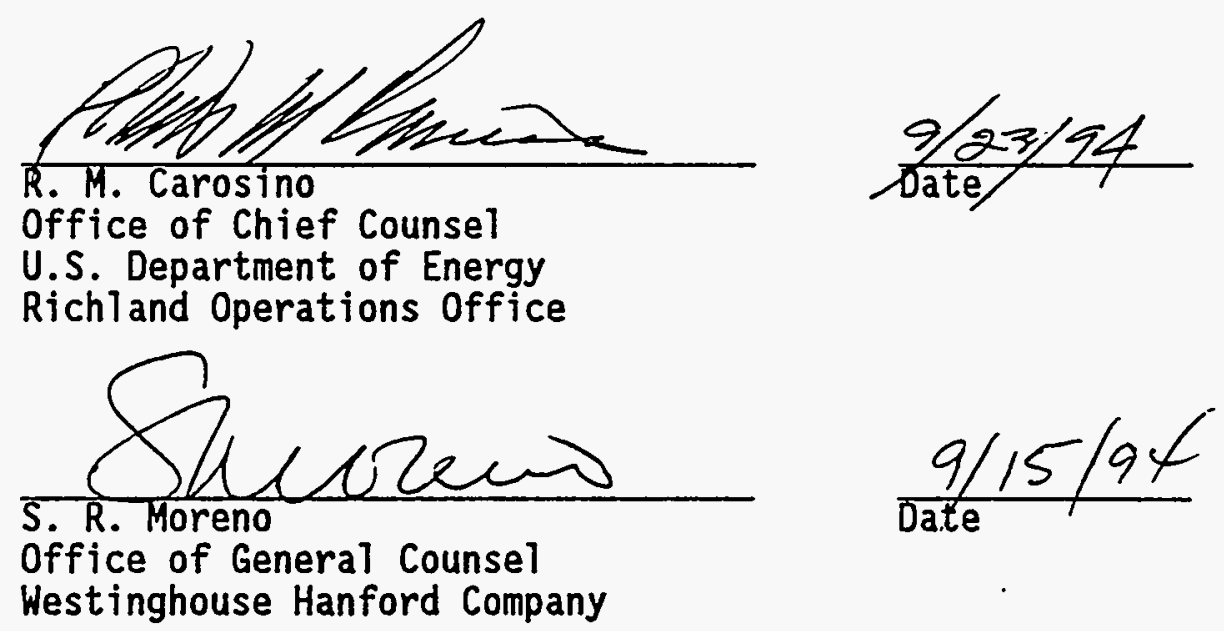




\begin{tabular}{|l|c|c|}
\hline 1.A Vision/Mission & $\begin{array}{c}\text { Westinghouse Hanford. Company } \\
\text { General Counsel's Office } \\
\text { SMS/WBS No. 6.10.5 }\end{array}$ & $\begin{array}{c}\text { FY } 1995 \\
\text { Site Support Program Plan } \\
\text { Date Prepared: } 09 / 94\end{array}$ \\
\hline
\end{tabular}

The General Counsel's office provides legal counsel to all levels of WHC management; administers the intellectual property program; coordinates al1 WHC investigative activity and supports WHC activities to ensure compliance with all applicable federal, state, and local laws, DOE directives, contractual provisions, and other requirements.

In so doing, the Office of General Counsel supports the Hanford site mission of transforming the Hanford site into an environmentally attractive and economically sustainable community. 


\begin{tabular}{|c|c|c|}
\hline & Westinghouse Hanford Company \\
General Counsel's Office & SMS/WBS No. 6.10.5 & $\begin{array}{c}\text { FY 1995 } \\
\text { Site Support Program P1an } \\
\text { Date Prepared: }\end{array}$ \\
\hline
\end{tabular}

\section{PRIMARY CUSTOMERS}

Interna 1: WHC management and programs

Externa1: DOE-RL and the Office of Inspector General

\section{PRODUCTS/SERVICES PROVIDED}

- Provide legal counsel to WHC management in all areas, including employment, security, environment, labor, equal employment opportunity, taxes, disputes, unemployment compensation, and health and safety matters.

- Represent WHC in all judicial or quasi-judicial proceedings and retain and overview any outside counsel representing WHC.

- Answer Privacy Act and Freedom of Information Act requests.

- Develop and administer WHC's conflict of interest policy and ethics program.

- Administer the intellectual property program.

- Review documents, speeches, articles, and manuals before publication or issue to the public for conformance with WHC patent and legal requirements.

- Coordinate all WHC investigative activities.

- Conduct nonsecurity-related reviews on behalf of management.

\section{EVALUATION OF MAJOR ACTIVITIES (COST, VALUE-ADDED, ETC.)}

Annual budget of approximately $\$ 3 M$. 


\begin{tabular}{|c|c|c|}
\hline 1.B.1 Internal Assessment Summary & $\begin{array}{c}\text { Westinghouse Hanford Company } \\
\text { General Counsel's Office } \\
\text { SMS/WBS No. 6.10.5 }\end{array}$ & $\begin{array}{c}\text { FY 1995 } \\
\text { Site Support Program Plan } \\
\text { Date Prepared: } 09 / 94\end{array}$ \\
\hline
\end{tabular}

\section{FACTORS WHICH INFLUENCE RESOURCE CONSUMPTION (CHANGES TO COST AND VOLUME)}

- Litigation - both defensive and offensive.

- Settlements - negotiations may result in settlements of either extreme.

- Mediation - mediators' suggested settlement may exceed assessed value.

- Administrative proceedings - permit appeals and hearings.

- Judgments - determined by judge or jury.

- New and/or amended statutes, regulations, directives, policies or guidelines.

- Contract modifications.

- Labor relations.

- Freedom of Information Requests.

- Tri-Party Agreement Milestones. 


\begin{tabular}{|c|c|c|}
\hline 1.B.2 External Assessment Summary & $\begin{array}{c}\text { Westinghouse Hanford Company } \\
\text { General Counsel's Office } \\
\text { SMS/WBS No. } 6.10 .5\end{array}$ & $\begin{array}{c}\text { FY 1995 } \\
\text { Site Support Program Plan } \\
\text { Date Prepared: } 09 / 94\end{array}$ \\
\hline
\end{tabular}

\title{
SUMMARY OF CUSTOMER REQUIREMENTS (NEEDS)
}

DOE Order 1100.3, "Office of Hearings and Appeals"

DOE Order 1700.1, "Freedom of Information Program"

DOE Order 1800.1A, "Privacy Act"

DOE Order 2030.4B, "Reporting Fraud, Waste, and Abuse to the Office of Inspector General"

DOE Order 4220.4, "Organizational Conflict of Interest Processing Procedures

RLIP 4220.2, "Organizational Conflict of Interest Processing Procedures

MRP 1.2, "Freedom of Information Act"

MRP 1.3, "Inventions, Copyrights and Trademarks"

MRP 1.4, "Proprietary and Business-Sensitive Information"

MRP 1.5, "Conflict of Interest"

MRP 1.22, "Conducting Internal Investigations"

MRP 1.24, "Interfacing With Outside Attorneys"

WHC Policies and Charters

Westinghouse Electric Corporation Policies and Directives

\section{OTHER EXTERNAL CHALLENGES}

\author{
Stakeholders \\ Regulators \\ Indian Tribes \\ Bid Protests \\ Litigation \\ Legal Constraints to Policy Decisions \\ Agency Actions \\ Union Organizing
}




\begin{tabular}{|l|c|c|}
\hline 1.C Goals and Objectives & $\begin{array}{c}\text { Westinghouse Hanford Company } \\
\text { General Counsel's Office } \\
\text { SMS/WBS No.6.10.5 }\end{array}$ & $\begin{array}{c}\text { FY 1995 } \\
\text { Site Support Program Plan } \\
\text { Date Prepared: } 09 / 94\end{array}$ \\
\hline
\end{tabular}

- Expand the scope of preventive law seminars.

- Implement a litigation management database.

- Tighten $\log$ controls on procurement requests for legal information.

- Promote a strong safety consciousness and maintain an injury-free work environment.

- Meet the needs of our internal and external customers in a timely manner.

- Anticipate where federal and state environmental requirements will impact WHC programs and activities and help develop feasible compliance options.

- Be proactive in finding ways to balance business goals and legal risks.

- Conduct prompt, thorough and objective investigations and reviews.

- Report all matters of fraud, waste and abuse to the Office of Inspector General within required time periods and as required by DOE Order.

- Develop and implement an effective and proactive business ethics program for WHC.

- Ensure prompt review and determination of inquiries regarding business ethics and conflict of interest matters.

- Ensure investigative reports and information are well documented and disseminated to appropriate organizations for corrective action.

Continue extraordinary accomplishments when presenting WHC's position to government agencies in response to charges/allegations which result in "no cause" to proceed determinations by the agencies (where applicable). 


\begin{tabular}{|l|c|c|}
\hline & Westinghouse Hanford Company & FY 1995 \\
1.C Goals and Objectives & SMS/WBS No. 6.10.5 & $\begin{array}{c}\text { Site Support Program Plan } \\
\text { Date Prepared: } 09 / 94\end{array}$ \\
\hline
\end{tabular}

- Continue the excellent settlement record in state and federal lawsuits in the labor and employment area.

- Avoid strikes, slowdowns and labor stoppages.

- Coordinate labor and employment policy with all site contractors.

- Continue to provide legal advice which prevents lawsuits/filings in the first place and results in a very low litigation expense in the labor and employment area. 


\begin{tabular}{|l|c|c|}
\hline 1.D Strategies & $\begin{array}{c}\text { Westinghouse Hanford Company } \\
\text { General Counsel's Office } \\
\text { SMS/WBS No. } 6.10 .5\end{array}$ & $\begin{array}{c}\text { FY 1995 } \\
\text { Site Support Program Plan } \\
\text { Date Prepared: } 09 / 94\end{array}$ \\
\hline
\end{tabular}

\section{ORGANIZATION and MANAGEMENT STRATEGIES}

- Practice preventive law to ensure a total quality and cost-effective utilization of resources.

- Provide necessary training opportunities to staff to enhance productivity and job satisfaction.

- Implement joint attorney meetings with DOE-RL on a monthly basis to discuss issues and concerns and improve staff relations.

- Define and coordinate subcontractor legal reporting responsibility. 


\begin{tabular}{|l|c|c|}
\hline & Westinghouse Hanford Company \\
General Counsel's Office & FY 1995 \\
SMS/WBS No. 6.10 .5 & $\begin{array}{c}\text { Site Support Program Plan } \\
\text { Date Prepared: } 09 / 94\end{array}$ \\
\hline
\end{tabular}

Compliance with all applicable federal, state and local laws, DOE directives, contractual provisions and other requirements. 
- Ensuring that employees and management learn to recognize the requirements of the law as it pertains to matters of fraud, waste and abuse, or conflicts of interest and timely report these matters as required by DOE Orders.

- The respective roles of DOE-RL and WHC on the Hanford Site limit WHC options in addressing environmental issues. For example, DOE-RL's RCRA responsibilities generally are for policy, programmatic, funding and scheduling decisions, as well as general oversight. The responsibilities of WHC are more limited. Environmental compliance must be answered through regular communication with responsible management on specific problems.

- The DOE implementation of NEPA is cumbersome and time-consuming. DOE is currently revising DOE Order 5440.1E regarding the DOE NEPA Compliance Program. Programs managed by WHC including privatization efforts are often unduly delayed while awaiting NEPA decisions. DOE-RL (and therefore WHC) compliance with NEPA may be perceived as being obstructionistic when complying with all NEPA requirements.

- Conflicting direction in major program areas.

- Lack of coordination by DOE programs at local and headquarters levels.

- Imposition of Contract Reform into a system whose rules have not changed and at times are inconsistent.

- Changing paradigms - facilitating transitions, be it in outsourcing or reduction in forces, and ensuring that ongoing operations continue to be conducted in compliance with all legal and policy requirements. 


\begin{tabular}{|l|c|c|}
\hline & Westinghouse Hanford Company & FY 1995 \\
General Counsel's Office & SMS/WBS No.6.10.5 & $\begin{array}{c}\text { Site Support Program Plan } \\
\text { Date Prepared 09/94 }\end{array}$ \\
\hline
\end{tabular}

Track implementation of goals and objectives (see Section 1.C). 


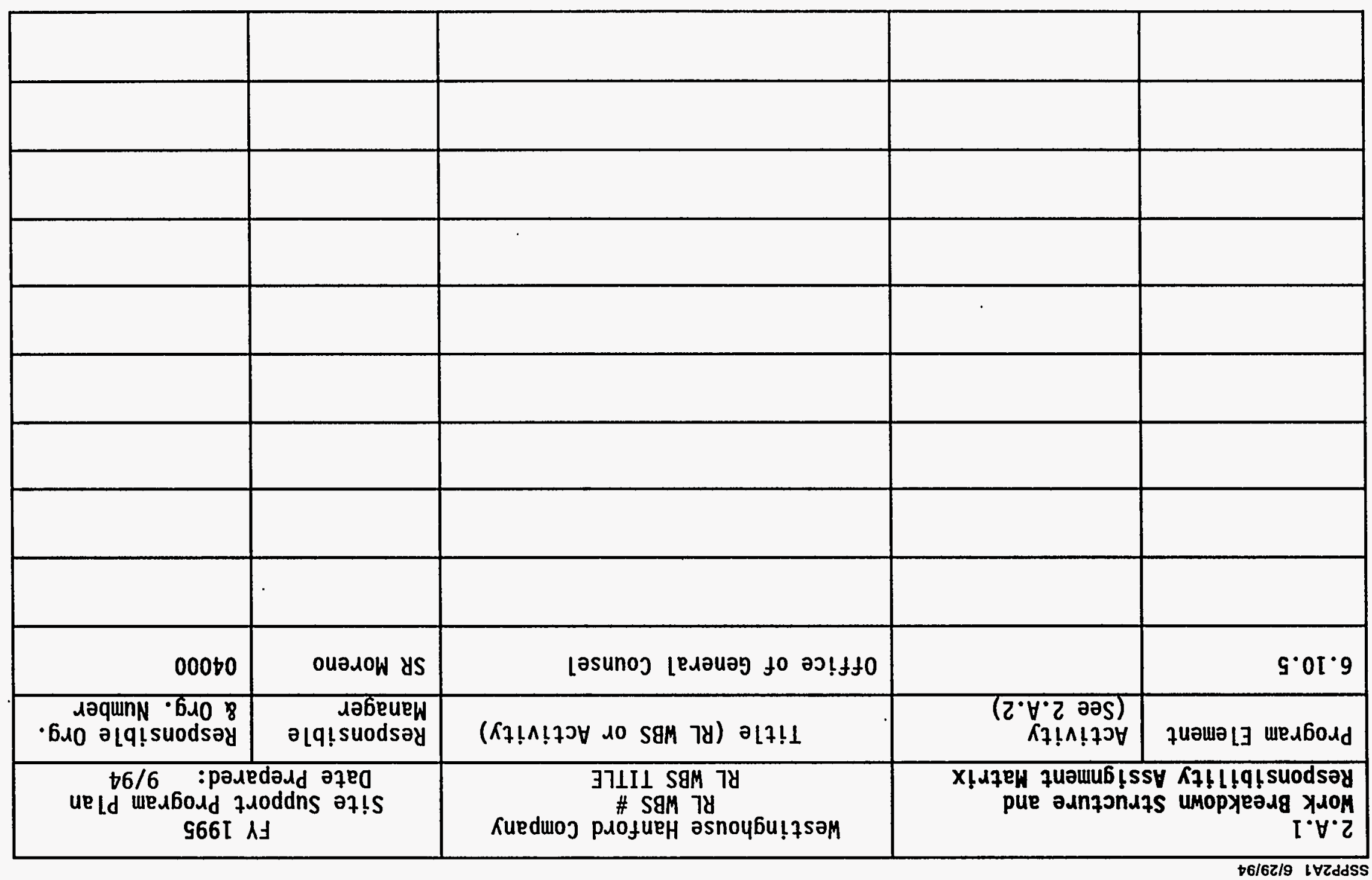




\begin{tabular}{|c|c|}
\hline 2.A.2 Description of Activities & $\begin{array}{c}\text { Westinghouse Hanford Company } \\
\text { RL WBS \# } \\
\text { RL WBS TITLE }\end{array}$ \\
\hline ACTIVITY NUMBER \& TITLE & DESCRIPTION \\
\hline Intellectual Property & $\begin{array}{l}\text { To manage intellectual property administration in areas such as } \\
\text { inventions/patents, copyrights and trademarks, and business } \\
\text { sensitive/proprietary information; to advise WHC personnel on all } \\
\text { intellectual property matters; to support software licensing and } \\
\text { the technology transfer, work for others/isotope sales programs; to } \\
\text { prepare and negotiate assignee, international and other agreements; } \\
\text { to assist the Office of General Counsel and other organizations; } \\
\text { and to interface with DOE-RL and WEC intellectual property } \\
\text { attorneys on intellectual property matters as required. }\end{array}$ \\
\hline Internal Review & $\begin{array}{l}\text { The Internal Review office was established as part of the office of } \\
\text { General Counsel to conduct investigations and reviews of internal } \\
\text { company matters and serve as the central point of contact for } \\
\text { coordination of company investigations. It has oversight and } \\
\text { responsibility for conducting investigations of matters pertaining } \\
\text { to fraud, waste and abuse of government funds, materials and } \\
\text { equipment, and the reporting and interface with the U.S. Department } \\
\text { of Energy office of Inspector General. As wel1, the Internal } \\
\text { Review office assists the Office of General Counsel with } \\
\text { investigative expertise in support of litigation matters involving } \\
\text { the company. } \\
\text { Additionally, the Internal Review office serves as the company } \\
\text { point of contact for clarification and interpretation of business } \\
\text { ethics matters and conducts ethics training for the company. }\end{array}$ \\
\hline Litigation/Procurement & $\begin{array}{l}\text { Litigation and litigation management } \\
\text { Government contracts } \\
\text { Price-Anderson Amendments Act } \\
\text { Freedom of Information Act and Privacy Act } \\
\text { General legal advice }\end{array}$ \\
\hline
\end{tabular}




\begin{tabular}{|c|c|}
\hline Labor & $\begin{array}{l}\text { The Office of General Counsel provides legal advice and } \\
\text { representation to the company in all labor and employment areas } \\
\text { including National Labor Relations Board, Equal Employment } \\
\text { Opportunity Commission, State of Washington Human Rights } \\
\text { Commission, Federal Department of Labor, State of Washington } \\
\text { Department of Labor and Industries and State of Washington } \\
\text { Employment Security Department (Unemployment). } \\
\text { In addition, matters relating to collective bargaining } \\
\text { (negotiating, labor agreement interpretation, grievances, } \\
\text { arbitrations), unemployment compensation, equal employment } \\
\text { opportunity, wage and hour, age, sex, national origin, disability } \\
\text { and race discrimination, employee protection provisions, internal } \\
\text { human resources policies including disciplinary procedures, } \\
\text { pensions/benefits, and layoff notices. } \\
\text { The office also assists outside counsel in state and federal court } \\
\text { litigation involving labor and employment law (research, discovery, } \\
\text { trial, briefs). }\end{array}$ \\
\hline Environmental Law & $\begin{array}{l}\text { Review and analyze environmental issues. Identify and propose } \\
\text { viable courses of action to maintain environmental compliance and } \\
\text { achieve WHC programmatic objectives. Provide aggressive, yet cost- } \\
\text { effective representation of WHC in environmental litigation and } \\
\text { negotiations. } \\
\text { Represent OGC on the WHC Central Environmental Committee (CEC) and } \\
\text { on the Executive Committee of the CEC. The CEC provides a means } \\
\text { for WHC programs to discuss environmental compliance issues in open } \\
\text { forum. The CEC provides for sharing of ideas, techniques and plans } \\
\text { for the resolution of issues and concerns. }\end{array}$ \\
\hline
\end{tabular}




\begin{tabular}{|c|c|c|}
\hline & Westinghouse Hanford Company & FY 1995 SSPP \\
Program Tit7e & Date Prepared: \\
by Program Element & RL WBS \# & $9 / 94$ \\
\hline
\end{tabular}

FY 1994 Cost Baseline (Dollars in Thousands)

\begin{tabular}{|l|l|l|}
\hline WBS * & Title & Total \$s \\
\hline 6.10 .5 & Office of General Counsel & $2,022 *$ \\
\hline & $\begin{array}{l}\text { Purchased Services are understated by 495k due to an over accrual in FY 93, } \\
\text { resulting in an accrual reversal of 700k with actual cost of 205k. } \\
\text { Purchased Services true FY 94 FYSF is 839k, for a true total of 2,517k. }\end{array}$ & \\
\hline & & \\
\hline & [Excludes company adders (G\&A and CSP/Oversight)] FY 1994 Total for (SMS/WBS No) & \\
\hline
\end{tabular}

FY 1995 Cost Baseline (Dollars in Thousands)

\begin{tabular}{|l|l|l|}
\hline 6.10 .5 & Office of General Counsel & 2,728 \\
\hline & & \\
\hline & & \\
\hline & [Excludes company adders (G\&A and CSP/Oversight)] FY 1995 Total for (SMS/WBS No) & \\
\hline
\end{tabular}




\begin{tabular}{|c|c|c|}
\hline $\begin{array}{l}\text { 2.C. } 1 \text { Cost Baseline } \\
\text { by Program Element }\end{array}$ & $\begin{array}{l}\text { Westinghouse Hanford Company } \\
\text { General Counsel's Office } \\
\text { SMS/WBS No. } 6.10 .5\end{array}$ & $\begin{array}{l}\text { FY } 1995 \text { SSPP } \\
\text { Date Prepared: }\end{array}$ \\
\hline
\end{tabular}

FY 1994 Cost Baseline (Dollars in Thousands)

\begin{tabular}{|l|l|l|}
\hline WBS \# & \multicolumn{1}{|c|}{ Title } & Total \$s \\
\hline 6.10 .5 & Office of General Counsel & $2,022 *$ \\
\hline & $\begin{array}{l}\text { Purchased Services is understated by 495k due to an over accrual in FY 93, } \\
\text { resulting in an accrual reversal of 700k with actual cost of 205k. } \\
\text { Purchased Services true FY 94 FYSF is 839k, for a true total of 2,517k. }\end{array}$ & \\
\hline & & \\
\hline & [Excludes company adders (G\&A and CSP/Oversight)] FY 1994 Tota] for (SMS/WBS No) & \\
\hline
\end{tabular}

\section{FY 1995 Cost Baseline (Dollars in Thousands)}

\begin{tabular}{|l|l|l|}
\hline 6.10 .5 & Office of General Counsel & 2,728 \\
\hline & & \\
\hline & & \\
\hline & & \\
\hline & [Excludes company adders (G\&A and CSP/Oversight)] FY 1995 Total for (SMS/WBS No) & \\
\hline
\end{tabular}




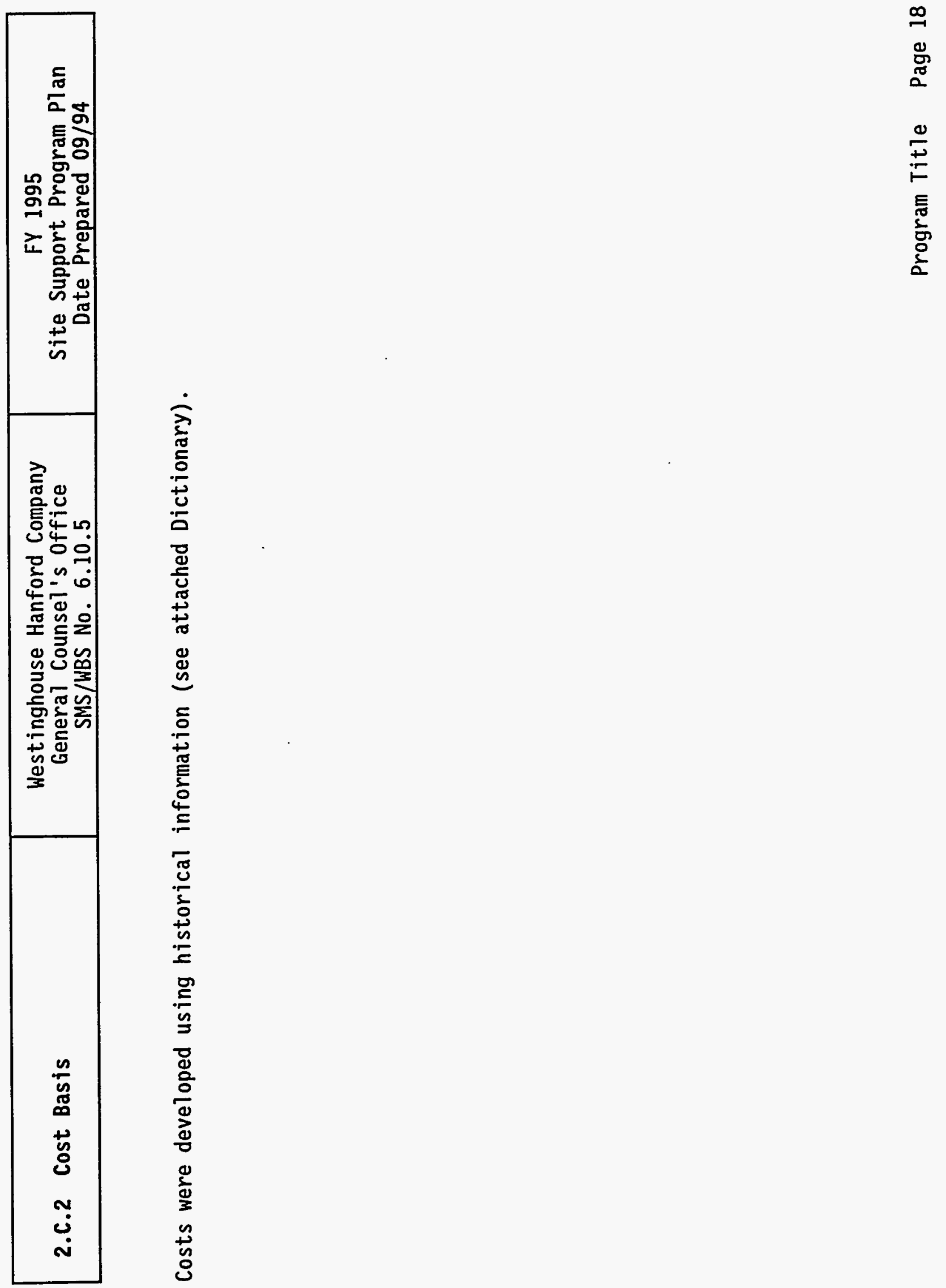


Full-Time Equivalent Staff by Job Description

*Intel lectua Prop. Adm.

Paralegal

Investigator

\begin{tabular}{|c|c|c|c|c|c|c|c|c|}
\hline \multicolumn{4}{|c|}{ Full-Time Equivalent Staff by Job Description } & \multicolumn{5}{|c|}{ NOTE: Job Family Only After 1996} \\
\hline Physicists & & & & & & & & \\
\hline Social & & & & & & & & \\
\hline other & & . & & & & & & \\
\hline APMINYOTHER PROFESSIOMALS & एल & & $\because \because \because$ & 16 & 16 & $16 \because$ & $\because 16$ & 16 \\
\hline Accountant/auditor & & & & & & & & \\
\hline Architect & & & & & & & & \\
\hline Buyers/procurement & & & & & & & & \\
\hline Communications & & & & & & & & \\
\hline Compl iance inspectors & & & & & & & & \\
\hline Computer System Anal & & & & & & & & \\
\hline Cost Est/planner/sch & & & & & & & & \\
\hline Heal th Physics & & & & & & & & \\
\hline Industrial Hygiene & & & & & & & & \\
\hline Lawyers & 6 & 6 & 6 & & & & & \\
\hline Personnel/Labor Rela & & & & & & & & \\
\hline Physicians & & & & & & & & \\
\hline Physician Assis/Murs & & & & & & & & \\
\hline Safeguard \& Security & & & & & & & & \\
\hline Tech Writers \& Edit & & & & & & & & \\
\hline Trainers & & & & & & & & \\
\hline S other * & 5 & 5 & 5 & & & & & \\
\hline JOB FAMILYY & $\therefore$ & & . & & & & & \\
\hline Job category & & & & & & & & \\
\hline GEN ADM/SECRETARYICLERK & $\because \cdots$ & & & & & & & \\
\hline Admin Assistants & & & & & & & & \\
\hline office Clerks (Gen) & & & & & & & & \\
\hline office clerks (Special) & 1 & 1 & 1 & & & & & \\
\hline Secretaries & 4 & 4 & 4 & & & & & \\
\hline
\end{tabular}




\begin{tabular}{|c|c|c|c|c|c|c|c|c|}
\hline \multicolumn{4}{|c|}{ Full-Time Equivalent Staff by Job Description } & \multicolumn{5}{|c|}{ NOTE : Job Family Only After 1996} \\
\hline JoB FAMIIY & अै। & कe... & : & $\therefore \therefore$ & $\because:$ & $\because \sqrt[3]{3}$ & $\because \because$ & $\because \therefore \because$ \\
\hline Job category & 1994 & 1995 & 1996 & 1997 & 1998 & 1999 & 2000 & 2001 \\
\hline MANAGERS $\because \because \because \because \quad \because$ & अ\$ & 5 & 5 & 5 & 5 & 5 & 5 & 5 \\
\hline \multicolumn{9}{|l|}{ First line } \\
\hline \multicolumn{9}{|l|}{ General/executive } \\
\hline \multicolumn{9}{|l|}{ Project/Program } \\
\hline \multicolumn{9}{|l|}{ other } \\
\hline ENGINEERS: : & +a: & $\because$ & $\cdots \cdots$ & & & $\because \because \because \because$ & $\because \cdots$ & $\because$ \\
\hline \multicolumn{9}{|l|}{ Chemical } \\
\hline \multicolumn{9}{|l|}{ Civil } \\
\hline \multicolumn{9}{|l|}{ Computer } \\
\hline \multicolumn{9}{|l|}{ Electrical } \\
\hline \multicolumn{9}{|l|}{ Envi ronmental } \\
\hline \multicolumn{9}{|l|}{ Industrial } \\
\hline \multicolumn{9}{|l|}{ Mechanical } \\
\hline \multicolumn{9}{|l|}{ Nuclear } \\
\hline \multicolumn{9}{|l|}{ Petroleum/Mining } \\
\hline \multicolumn{9}{|l|}{ Plant } \\
\hline \multicolumn{9}{|l|}{ Quality Control } \\
\hline \multicolumn{9}{|l|}{ Safety } \\
\hline \multicolumn{9}{|l|}{ other } \\
\hline \multicolumn{9}{|l|}{ SCIENTISTS } \\
\hline \multicolumn{9}{|l|}{ Chemists } \\
\hline \multicolumn{9}{|l|}{ Environmental } \\
\hline \multicolumn{9}{|l|}{ Geologists } \\
\hline \multicolumn{9}{|l|}{ Life } \\
\hline \multicolumn{9}{|l|}{ Material } \\
\hline Mathematicians & & & & & & & & \\
\hline
\end{tabular}




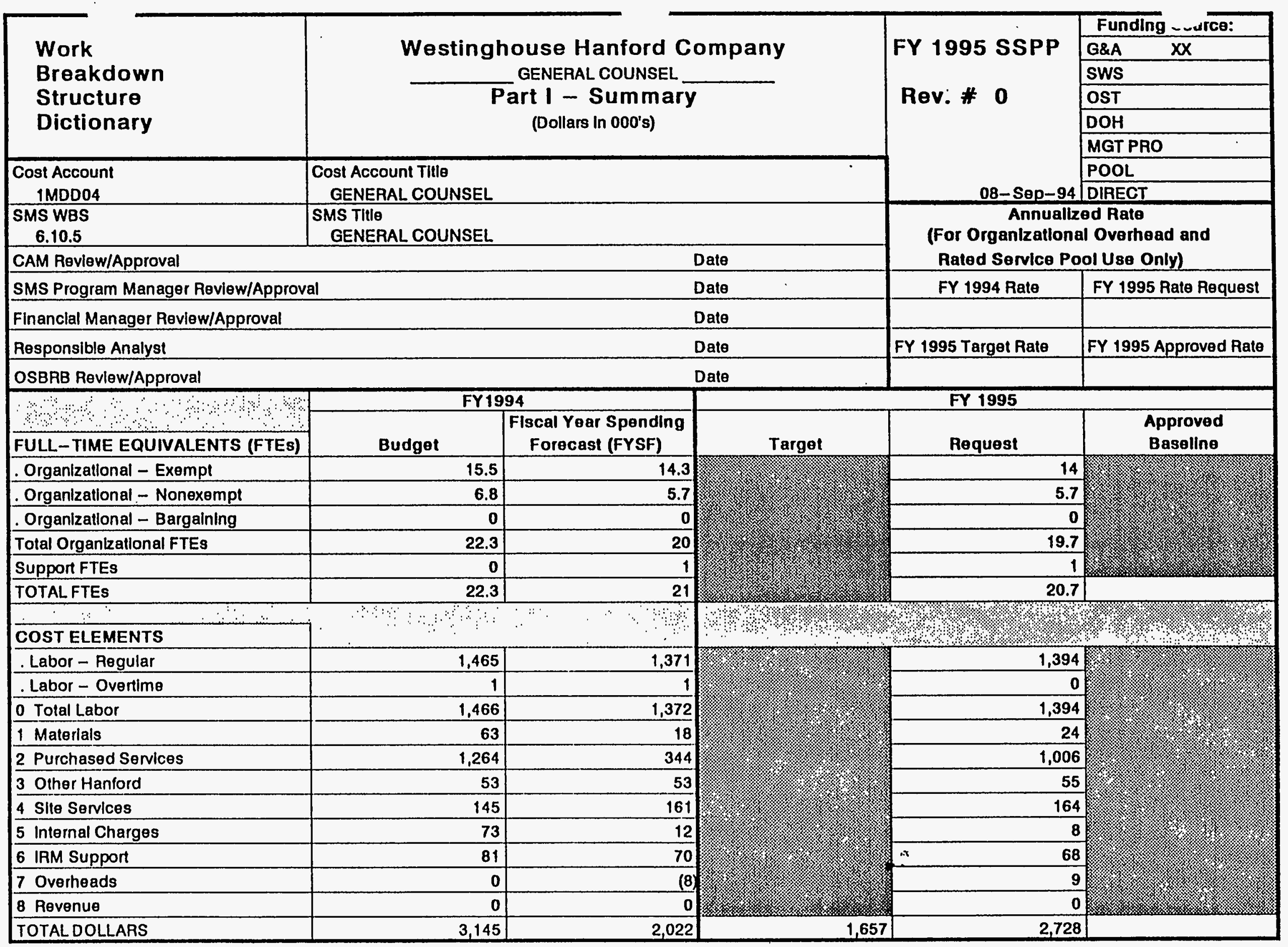




\begin{tabular}{|l|c|c|}
\hline $\begin{array}{l}1 \text { Mud04 } \\
\text { COST ACCOUNT }\end{array}$ & & FY 1995 SSPP \\
\hline $\begin{array}{l}\text { Work Breakdown } \\
\text { Structure } \\
\text { Dictionary }\end{array}$ & $\begin{array}{c}\text { Westinghouse Hanford Company } \\
\text { GENERAL CounseL }\end{array}$ & Revision \# 0 \\
\hline
\end{tabular}

\begin{tabular}{|l|l|}
\hline WBS ELEMENT CODE: $\quad 6.10 .5$ & TITLE: GENERAL COUNSEL \\
\hline ELEMENT TASKDESCRIPTION
\end{tabular}

\section{COST CONTENT -}

The WHC Offlce of General Counsel (OGC) is G\&A funded.

\section{TECHNICAL CONTENT -}

The OGC supports the mission by providing legal counsel In all areas; administering the intellectual property/technology transfer program; supporting DOE In responding to Privacy Act and Freedom of Information Act requests; conducting nonsecurity reviews on behalf of management; and coordinating all Invesitgatlve activily undertaken by WHC.

\section{OBJECTIVES -}

The objectives of the OGC are to ensure compliance with all appllcable legal requirements, contractual provislons, DOE directives, WHC and DOE policies and procedures and to work constructively with DOE and other Hanford contractors to resolve legal lssues which arlse at the Hanford Site.

\section{ASSUMPTIONS/CONSTRAINTS -}

It is assumed that there will be no major changes In the emphasis or volume of work in the foreseeable future, although the practice is currently quite demanding, particularly in the environmental, litlgatlon and labor areas. Program constraints are based upan contract provislons, legal requirements and constraints on other programs being supported.

\section{MILESTONES -}

There are no milestones associated with OGC.

\section{DELIVERABLES -}

In addition to the monthly SMS report, OGC provides perlodic input to DOE's litigation database and various reports, from time to time as appropriate, to keep DOE Chlef Counsel Informed on Issues and to coordinate activitles. 


\section{WORK STATEMENT -}

\section{REQUESTS WITHIN TARGET:}

Activity Detalled Description

General Counsel provldes legal counsel in all areas, ensures compllance with all legal requlrements, and coordinates WHC Investigative activity.

The legal department conslsts of 5 Managers, 4 secretarles, 1 clerk, $1 \mathrm{COE}$, and 10 attorneys/support statt.

The non-labor costs include occupancy of 150k, telephone of $30 \mathrm{k}$, 75k. for business travel \& relocation, $35 \mathrm{k}$ for various tralning, $40 \mathrm{k}$ for legal publicatlons, and computer purchases \& assessments of $50 \mathrm{k}$.

(2.1 of the above FTE's are in the request above target section. 62k of the 2.1 FTE cost is due to a labor rate increase. The remaining $109 \mathrm{k}$ of labor moved to the over target sectlon was done to be within the unreasonably low target.)

The increase in non-labor dollars is due to expected relocation, 30k, $8 \mathrm{k}$ in computer purchases, 45k over-accrual in $\mathrm{FY94}$, and $45 \mathrm{~K}$ in travel and training.

\section{REQUESTS ABOVE TARGET:}

\section{Activity Detalled Description}

The legal fees work scope is any outside legal assistance required by the legal department.

FY 94 legal fees are understated by 500k due to an over-accrual.

\section{Actlvity Detalied Description}

See request within target section.

Labor Cost Non-Labor Cost

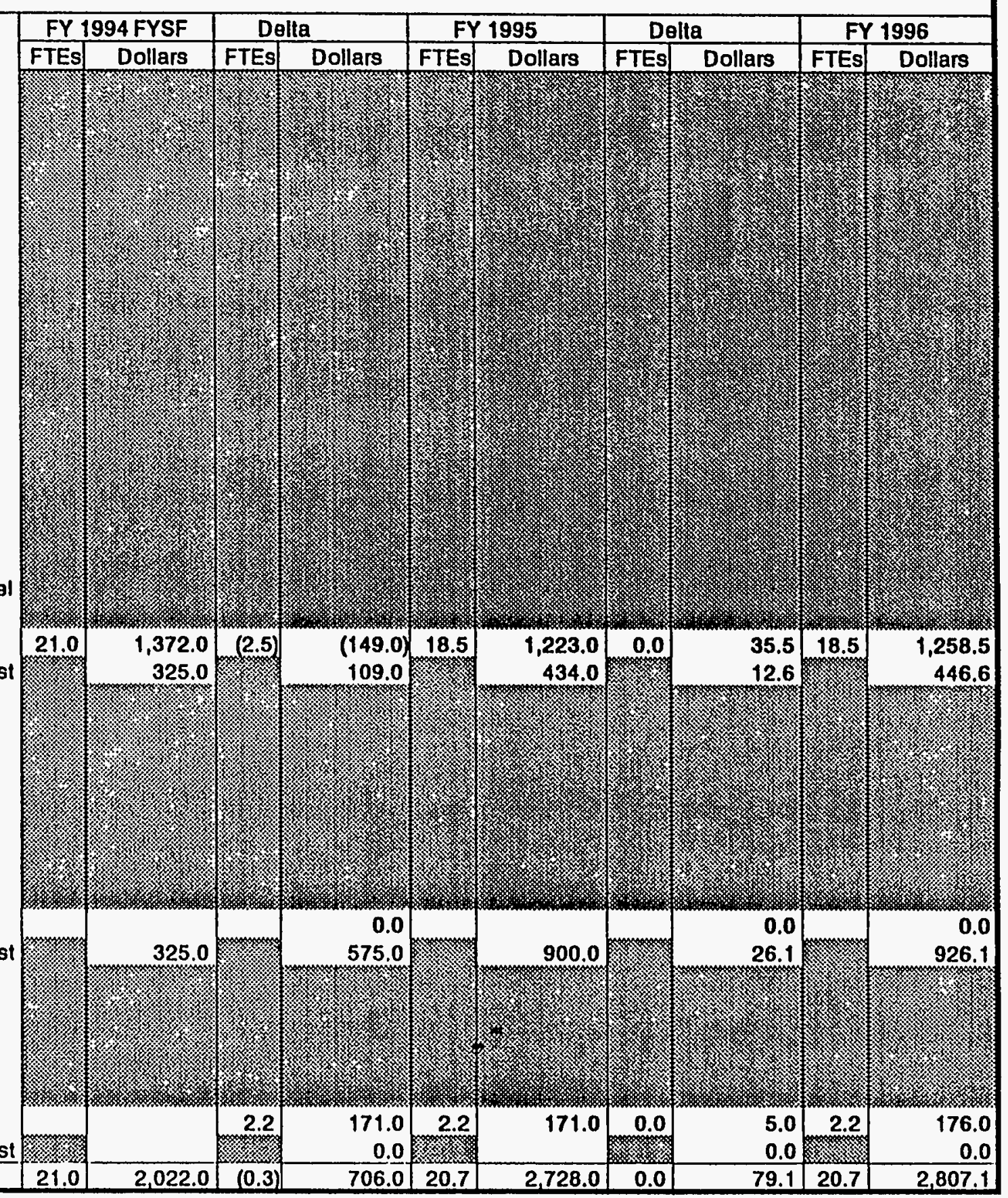

